\title{
Corrigendum: Iron and Cadmium Entry Into Renal Mitochondria: Physiological and Toxicological Implications
}

\author{
Frank Thévenod ${ }^{1 *}$, Wing-Kee Lee ${ }^{1}$ and Michael D. Garrick ${ }^{2}$ \\ ${ }^{1}$ Faculty of Health, Centre for Biomedical Education and Research, Institute of Physiology, Pathophysiology and Toxicology, \\ Witten/Herdecke University, Witten, Germany, ${ }^{2}$ Department of Biochemistry, Jacobs School of Medicine and Biomedical \\ Sciences, University at Buffalo, Buffalo, NY, United States
}

Keywords: reactive oxygen species, divalent metal transporter 1, ionic mimicry, manganese, copper, nephrotoxicity, acute kidney injury, chronic kidney disease

OPEN ACCESS

Approved by:

Frontiers Editorial Office Frontiers Media SA, Switzerland

*Correspondence: Frank Thévenod frank.thevenod@uni-wh.de

Specialty section:

This article was submitted to Mitochondrial Research,

a section of the journal Frontiers in Cell and Developmental

Biology

Received: 30 March 2021 Accepted: 31 March 2021

Published: 19 April 2021

Citation:

Thévenod F, Lee W-K and Garrick MD (2021) Corrigendum: Iron and

Cadmium Entry Into Renal Mitochondria: Physiological and

Toxicological Implications.

Front. Cell Dev. Biol. 9:687810. doi: 10.3389/fcell.2021.687810

\section{A Corrigendum on}

Iron and Cadmium Entry Into Renal Mitochondria: Physiological and Toxicological Implications

by Thévenod, F., Lee, W.-K., and Garrick, M. D. (2020). Front. Cell Dev. Biol. 8:848. doi: $10.3389 /$ fcell.2020.00848

In the published article, there was an error in the Funding statement for MG. The corrected paragraph appears below:

\section{FUNDING}

FT received funding from BMBF (01DN16039), DFG (TH345), and ZBAF. MG appreciates the support of grant R01 DK109717 from the National Institute of Diabetes and Digestive and Kidney Diseases and the Office of Dietary Supplements. W-KL received financial support through the Intramural Funding Program at Witten/Herdecke University (IFF 2018-52).

The authors apologize for this error and state that this does not change the scientific conclusions of the article in any way. The original article has been updated.

Copyright $\odot 2021$ Thévenod, Lee and Garrick. This is an open-access article distributed under the terms of the Creative Commons Attribution License (CC BY). The use, distribution or reproduction in other forums is permitted, provided the original author(s) and the copyright owner(s) are credited and that the original publication in this journal is cited, in accordance with accepted academic practice. No use, distribution or reproduction is permitted which does not comply with these terms. 